\title{
Complete sucrose hydrolysis by heat-killed recombinant Pichia pastoris cells entrapped in calcium alginate
}

\author{
Duniesky Martínez ${ }^{1}$, Carmen Menéndez ${ }^{2}$, Félix M Echemendia ${ }^{1}$ Enrique R Pérez ${ }^{1}$, Luis E Trujillo ${ }^{2 *}$, Alina Sobrino ${ }^{1}$,
} Ricardo Ramírez², Yamira Quintero ${ }^{2}$ and Lázaro Hernández²

\begin{abstract}
Background: An ideal immobilized biocatalyst for the industrial-scale production of invert sugar should stably operate at elevated temperatures $\left(60-70^{\circ} \mathrm{C}\right.$ ) and high sucrose concentrations (above $60 \%, \mathrm{w} / \mathrm{v}$ ). Commercial invertase from the yeast Saccharomyces cerevisiae is thermolabile and suffers from substrate inhibition. Thermotoga maritima $\beta$-fructosidase (BfrA) is the most thermoactive and thermostable sucrose-hydrolysing enzyme so far identified and allows complete inversion of the substrate in highly concentrated solutions.
\end{abstract}

Results: In this study, heat-killed Pichia pastoris cells bearing N-glycosylated BfrA in the periplasmic space were entrapped in calcium alginate beads. The immobilized recombinant yeast showed maximal sucrose hydrolysis at pH 5-7 and $90^{\circ} \mathrm{C}$. BfrA was $65 \%$ active at $60^{\circ} \mathrm{C}$ and had no activity loss after incubation without the substrate at this temperature for $15 \mathrm{~h}$. Complete inversion of cane sugar $(2.04 \mathrm{M})$ at $60^{\circ} \mathrm{C}$ was achieved in batchwise and continuous operation with respective productivities of 4.37 and 0.88 gram of substrate hydrolysed per gram of dry beads per hour. The half-life values of the biocatalyst were 14 and 20 days when operated at $60^{\circ} \mathrm{C}$ in the stirred tank and the fixed-bed column, respectively. The reaction with non-viable cells prevented the occurrence of sucrose fermentation and the formation of by-products. Six-month storage of the biocatalyst in $1.46 \mathrm{M}$ sucrose $(\mathrm{pH} 5.5)$ at $4^{\circ} \mathrm{C}$ caused no reduction of the invertase activity.

Conclusions: The features of the novel thermostable biocatalyst developed in this study are more attractive than those of immobilized S. cerevisiae cells for application in the enzymatic manufacture of inverted sugar syrup in batch and fixed-bed reactors.

Keywords: Pichia pastoris, Thermotoga maritima, Invertase, Immobilization, Alginate

\section{Background}

The hydrolysis of sucrose generates an equimolar mixture of fructose and glucose, commercially known as invert sugar. The inverted sugar syrup is sweeter than sucrose and easier to incorporate in food and pharmaceutical preparations since it does not show the crystallization problems of its precursor in highly concentrated solutions. Sucrose inversion can be achieved by acid hydrolysis or by using invertase (EC 3.2.1.26) or exoinulinase (EC 3.2.1.80). The enzymatic process

\footnotetext{
* Correspondence: luis.trujillo@cigb.edu.cu

2Plant-Microbe Interactions Laboratory, Center for Genetic Engineering and Biotechnology (CIGB), Ave 31 entre 158 y 190, Apartado Postal 6162, Habana 10600, Cuba

Full list of author information is available at the end of the article
}

produces food-grade syrups which are devoid of the brown colour and the toxic by-product hydroxymethylfurfural (HMF) present in the acid inverted syrup. The mesophilic yeast Saccharomyces cerevisiae is by far the main source of enzyme for the commercial production of invert sugar. The yeast periplasmic invertase (SUC2) is a glycoprotein optimally active at $\mathrm{pH} 4.5-5.0$ and $55-60^{\circ} \mathrm{C}$, but its activity in immobilized biocatalysts drops drastically during repeated operation at temperature above $50^{\circ} \mathrm{C}[1-3]$.

Entrapment in insoluble calcium alginate gel is recognized as a simple, inexpensive, and non-toxic method for immobilization of enzymes and cells with applications in the food and pharmaceutical industries [4]. 
Several authors have entrapped partially purified SUC2 or $S$. cerevisiae cells in alginate gels for continuous production of invert sugar [5-9]. Immobilization of the whole yeast cells offers economic advantages over immobilization of soluble invertase. The use of immobilized cells prevents the enzyme from leaking out of the Ca-alginate beads, but may cause technical troubles during operation if the confined yeast remains alive. The sucrose fermentation products ethanol and acetate are undesired contaminants in the invert syrup while the release of $\mathrm{CO}_{2}$ bubbles increases the internal pressure of packed-bed columns which then tend to crack [10]. The entrapped cells can be killed with retention of the invertase activity by exposing the beads to gamma-irradiation [11], but this method is costly and not recommended for use in the food industry. Alternatively, a heat-killing process applied to $S$. cerevisiae would inactivate its thermolabile invertase.

The search for invertase or exoinulinase enzymes capable to operate at pasteurisation temperature $\left(60-70^{\circ} \mathrm{C}\right)$ has been conducted in bacteria [12], yeast [13,14] and fungi [15-18]. Thermotoga maritima $\beta$-fructosidase (BfrA) is the most thermoactive and thermostable sucrosehydrolysing enzyme so far identified. BfrA has been produced intracellularly in Escherichia coli [12,19] and as a secreted enzyme in Pichia pastoris [20]. The nonsaccharolytic yeast $P$. pastoris is a Generally Recognized As Safe (GRAS) host appropriate to produce recombinant enzymes with applications in the sugar and food industries [21-23]. BfrA secretion by recombinant $P$. pastoris resulted in high invertase activity both in the periplasmic space and the growth medium offering the dual possibility of cell and enzyme immobilization [20,24].

This study is aimed to develop a thermostable biocatalyst based on the immobilization of non-viable cells for the enzymatic production of invert sugar. Heat-killed $P$. pastoris cells containing recombinant BfrA in the periplasmic space were entrapped in calcium alginate beads and compared with the free cells in terms of optimal conditions for activity, catalytic properties, and thermal stability. The immobilized biocatalyst completely hydrolysed cane sugar in highly concentrated solutions operating at high temperatures in batch and fixed-bed reactors.

\section{Results and discussion}

\section{Exponential fed-batch fermentation of recombinant} Pichia pastoris enhanced periplasmic retention of N-glycosylated BfrA

Pichia pastoris strain PpBfrA $(4 \times)$ constitutively expressing four copies of the Thermotoga maritima bfrA gene was assayed for production of the recombinant enzyme in fed-batch fermentation experiments conducted for $54 \mathrm{~h}$ using lineal and exponential feeding of cane sugar as the sole carbon source (Figure 1). At the end of the lineal fed-batch fermentation, the cell mass reached $84 \mathrm{~g} / \mathrm{L}$ (dry biomass) and BfrA was secreted to the periplasmic space (54\%) and the culture medium (46\%) with a global volumetric productivity of $5735 \mathrm{U} / \mathrm{L} / \mathrm{h}$. The sum of the invertase activities in the undisrupted biomass (1995 U/g, dry weight) and the culture supernatant (142.1 U/mL) provides an overall BfrA yield of $309.7 \mathrm{U}$ per $\mathrm{mL}$ of fermentation culture. The change to exponential feeding caused a reduction in the final values of cell density (70 g/L, dry biomass), extracellular invertase activity $(69.6 \mathrm{U} / \mathrm{mL})$, overall BfrA yield $(251.8 \mathrm{U} / \mathrm{mL})$ and volumetric productivity $(4662 \mathrm{U} / \mathrm{L} / \mathrm{h})$. By contrast, the specific activity of the dry biomass $(2603 \mathrm{U} / \mathrm{g})$ increased 1.3 fold. The periplasmic/extracellular rate of invertase activity improved from 1.17 in the linear feeding to 2.61 in the exponential one. Recombinant $P$. pastoris cells grew on sucrose by a respiratory route achieving yield coefficients of 0.60 and $0.47 \mathrm{~g}$ dry biomass/g of sucrose for the lineal and exponential feeding strategies, respectively.

BfrA was extracted from the cell periplasm with purity above $90 \%$ by using a mild chemical treatment. As we have already reported for the enzyme purified from the culture supernatant [20], periplasmic BfrA migrated on SDS-PAGE as two bands of different $\mathrm{N}$-glycosylation degrees with estimated molecular masses of 58 and $53 \mathrm{kDa}$ (Figure 2, lane 2). The treatment with endoglycosidase $\mathrm{H}_{\mathrm{f}}$ produced a deglycosylated protein with the expected size of $51 \mathrm{kDa}$ (Figure 2, lane 3).

Pichia pastoris bearing periplasmic BfrA hydrolysed sucrose without the need of a cell permeabilization treatment, confirming that the substrate diffuses readily through the cell wall. Direct sucrose conversion in the periplasmic space has been reported for non-permeabilized cells of native $S$. cerevisiae [25] and recombinant $P$. pastoris secreting sucrose-modifying enzymes of different origins [26-28].

\section{Calcium alginate entrapment of heat-killed cells}

Sucrose inversion by immobilized living yeast cells occurs with simultaneous substrate fermentation, which causes technical troubles as well as a decrease in the yield and quality of the inverted syrup. In this study, recombinant $P$. pastoris cells bearing the highly thermostable BfrA were submitted to a heat-killing process prior to calcium alginate entrapment. The invertase activity of the non-viable cells (3092 U/g, dry weight) increased almost 1.2-fold in comparison to the untreated cells (2603 U/g, dry weight). After biomass disruption, the soluble extracts of the viable and heat-killed cells showed no differences in their BfrA activity (3189 U/g, dry weight). Our findings suggest that heat exposition altered the cell wall structure in a way that facilitates sucrose diffusion to the periplasmic space. An alternative treatment with $70 \%$ ethanol for $15 \mathrm{~min}$ at $30^{\circ} \mathrm{C}$ succeeded to kill the $P$. pastoris cells but inactivated the periplasmic BfrA (data not shown). 


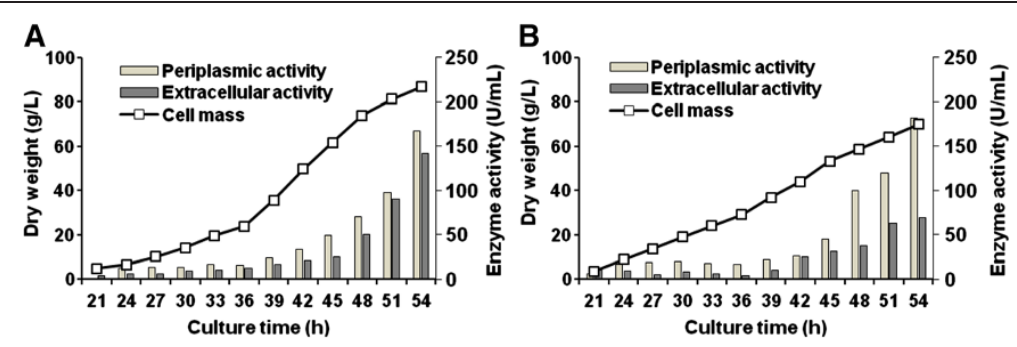

Figure 1 BfrA production by recombinant Pichia pastoris strain PpBfrA (4x) during lineal (A) and exponential (B) fed-batch fermentation.

Figure 3 shows the effect of biomass concentration (50-400 g/L, wet weight) on calcium alginate entrapment of the heat-killed cells. Maximal values of immobilization yield $(99.6 \%)$ and invertase activity $(102.9 \mathrm{U} / \mathrm{g}$ of dry bead) were achieved with biomass loading of $300 \mathrm{~g} / \mathrm{L}$. The immobilization of the most concentrated biomass $(400 \mathrm{~g} / \mathrm{L})$ restricted the internal diffusion of the substrate sucrose resulting in calcium-alginate beads of lower specific activity (90.7 U/g of dry bead). Cell entrapment of S. cerevisiae or Bacillus macerans at high biomass/ alginate ratios did not favour the increase of intracellular invertase activity [29,30].

The entrapped cells retained $100 \%$ and $80 \%$ of its original invertase activity during storage in $1.46 \mathrm{M}$ sucrose at $\mathrm{pH} 5.5$ and $4^{\circ} \mathrm{C}$ for 6 and 12 months, respectively. The cold storage of the Ca-alginate beads in a highly concentrated sucrose solution avoided microbial contamination and

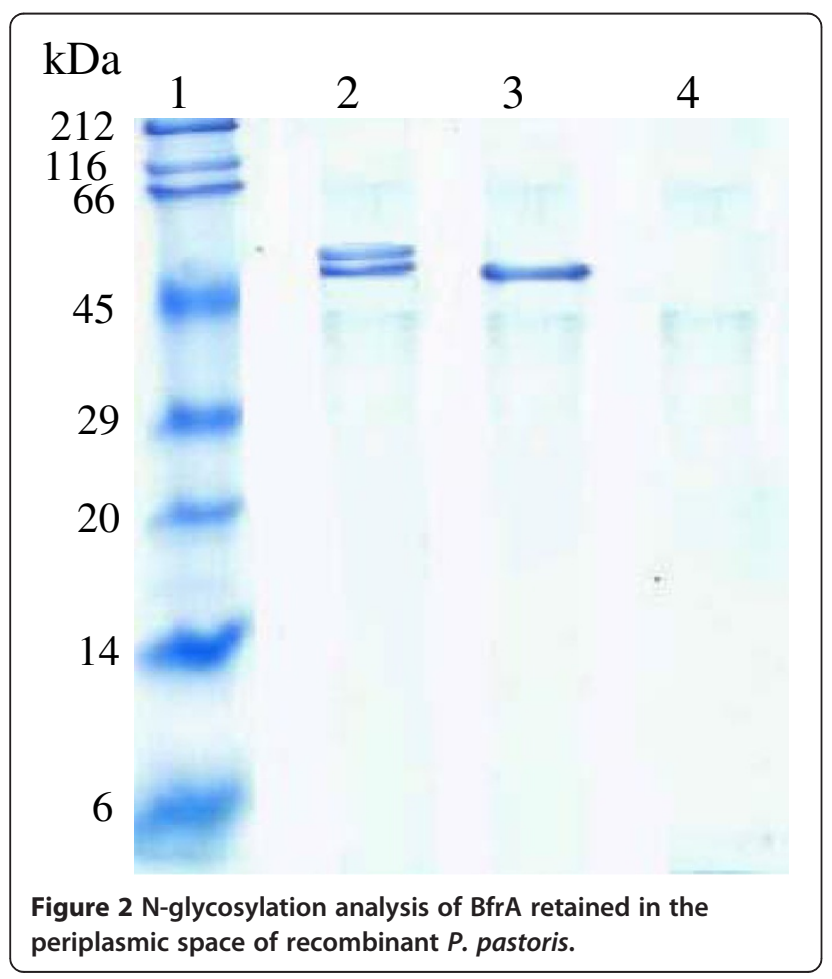

allowed no important substrate dilution upon operation. Calcium alginate entrapment of free BfrA recovered from the culture supernatant resulted in a low immobilization yield and most of the entrapped enzyme leaked out of the beads during storage (data not shown).

\section{Effects of pH and temperature on BfrA activity in free and immobilized cells}

The effect of $\mathrm{pH}$ on sucrose hydrolysis by the non-viable Pichia cells in free or immobilized form was evaluated in the range $3-8$ at $60^{\circ} \mathrm{C}$ (Figure $4 \mathrm{~A}$ ). The invertase activity of the free cells was maximum at $\mathrm{pH} 6$ and decreased by at least fourfold in the reactions at the $\mathrm{pH}$ values 3,4 and 8 . The entrapped cells showed a less pronounced $\mathrm{pH}$-activity curve with maximal hydrolysis rates in the optimum $\mathrm{pH}$ range $5-7$ and relative activities above $40 \%$ at the extreme $\mathrm{pH}$ values 3 and 8 . Broadening of the $\mathrm{pH}$ profile was also observed for $S$. cerevisiae invertase after immobilization on calcium alginate $[5,31]$

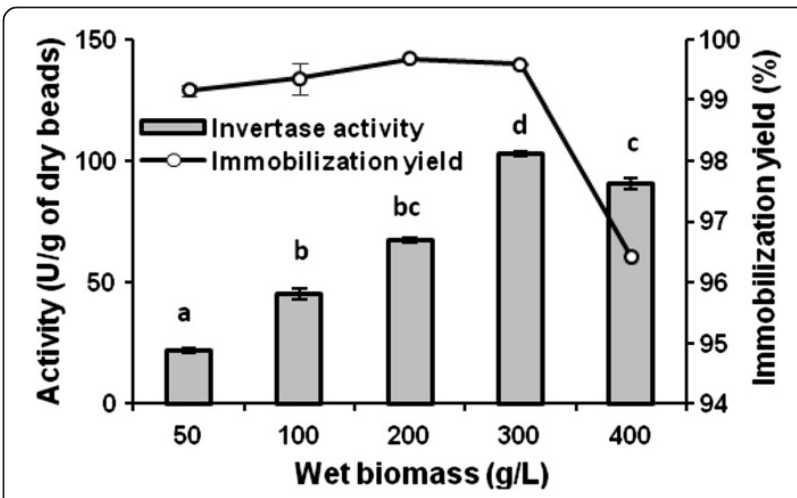

Figure 3 Effect of biomass loading on the cell entrapment efficiency and the invertase activity. Non-viable cell suspensions at final concentrations of 50, 100, 200, 300, and $400 \mathrm{~g} / \mathrm{L}$ (wet biomass) were subjected to calcium alginate entrapment. The beads invertase activity was determined for sucrose (120 mM) hydrolysis at pH 5.5 and $60^{\circ} \mathrm{C}$ using the DNSA method. Immobilization yield expresses the percentage of initial invertase activity which was not recovered in the entrapped cells but remained in the $\mathrm{CaCl}_{2}$ solution. Data are the means of triplicate measurements \pm standard deviation. Different letters are significantly differences between invertase activity for each quantity of biomass loading (Student-Newman-Keuls test, $a=0.05$ ). 

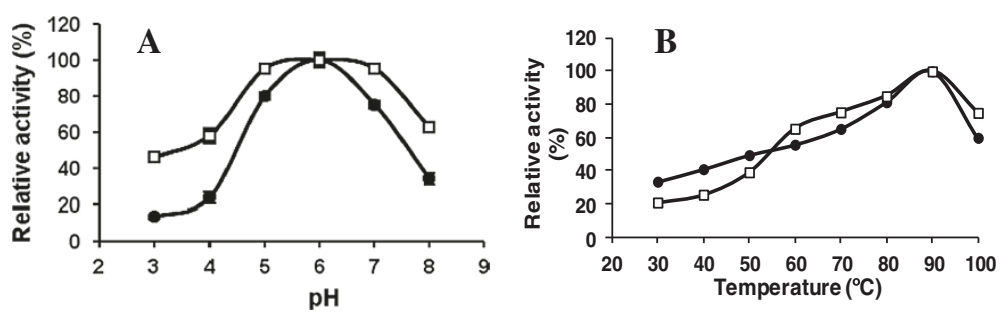

Figure 4 Effect of pH (A) and temperature (B) on BfrA activity in free (•) and immobilized ( $\square$ ) cells.

or other supports [32-34]. Cell entrapment did not markedly influence the optimal $\mathrm{pH}$ conditions for BfrA activity, suggesting no changes in net charge of the biocatalyst. By contrast, immobilization of this enzyme on glyoxylsepharose CL-4B caused an acidic shift in the $\mathrm{pH}$-activity profile, with the maximum value of sucrose hydrolysis occurring at $\mathrm{pH} 5$ [24]. Similarly, the type of support and the immobilization method were found to be important factors influencing the performance of $S$. cerevisiae invertase at different reaction conditions [35,36].

The effects of $\mathrm{pH}$ and temperature on invertase activity of free and immobilized cells were evaluated in the ranges $3-8$ and $30-100^{\circ} \mathrm{C}$, respectively (Figure 4 ). Sucrose hydrolysis by the free heat-killed cells was maximum at $\mathrm{pH} 6$ and $90^{\circ} \mathrm{C}$. These values are similar to those reported for non-glycosylated BfrA produced in Escherichia coli [12] and $\mathrm{N}$-glycosylated BfrA purified from the culture supernatant of P. pastoris $\mathrm{PpBfrA}(4 \mathrm{x})$ [20]. The entrapped cells showed a wider optimal $\mathrm{pH}$ range (5-7) and higher relative activities (above 40\%) at the extreme $\mathrm{pH}$ values 3 and 8 when comparing to the $\mathrm{pH}$-activity curve of the free cells (Figure 4A). Broadening of the $\mathrm{pH}$ profile was also observed for S. cerevisiae invertase afterimmobilization on calcium alginate $[5,36]$ or other supports [37-39]. The temperature-activity curves of the free and immobilized cells were almost identical with maximal sucrose hydrolysis at $90^{\circ} \mathrm{C}$ and relative activity above $60 \%$ at $60-70^{\circ} \mathrm{C}$, the temperature range most recommended for industrial operation (Figure 4B).

The influence of temperature on the invertase activity of free and immobilized cells was examined in the range $30-100^{\circ} \mathrm{C}$ with the $\mathrm{pH}$ value fixed at 5.5 (Figure $4 \mathrm{~B}$ ). The temperature-activity curves of the free and entrapped cells were almost identical with maximal sucrose hydrolysis at $90^{\circ} \mathrm{C}$. The immobilized biocatalyst behaved threefold less active when the reaction temperature was set at $50^{\circ} \mathrm{C}$, but its relative activity remained above $65 \%$ for the reactions at 60 and $70^{\circ} \mathrm{C}$, which are the most recommended temperatures for operation in the sugar industry. Optimum temperature values between $80-90^{\circ} \mathrm{C}$ were previously reported for the non-glycosylated BfrA produced in Escherichia coli [12] and the N-glycosylated enzyme in free or immobilized form $[20,24]$.

\section{Effect of cell entrapment on BfrA thermal stability}

The immobilized cells retained 100, 89, 59 and $37 \%$ of the initial BfrA activity after incubation without substrate for $15 \mathrm{~h}$ at $60,70,80$ and $90^{\circ} \mathrm{C}$, respectively (Figure 5). The remaining invertase activity of the free cells dropped at a higher rate for all the tested temperatures. Calcium alginate encapsulation provides a physical barrier that protects periplasmic BfrA from heat inactivation and/or leakage out of the entrapped cells. Enhanced thermal stability was previously reported for S. cerevisiae invertase immobilized within Ca-alginate beads [7].

\section{Kinetic parameters and activation energy of BfrA in free and immobilized cells}

$\mathrm{N}$-glycosylated BfrA is known to suffer from slight inhibition at sucrose levels above $584 \mathrm{mM}(20 \% \mathrm{w} / \mathrm{v})$ [20]. The kinetic behaviour of periplasmic BfrA in free and immobilized cells was assayed using non-inhibitory substrate concentrations $(10-200 \mathrm{mM})$ at $\mathrm{pH} 5.5$ and $60^{\circ} \mathrm{C}$. The parameter $V_{\max }$ was determined to be $400 \mu \mathrm{mol} / \mathrm{min} / \mathrm{g}$ and $48 \mu \mathrm{mol} / \mathrm{min} / \mathrm{g}$ for the free and immobilized cells, respectively. The $K_{\mathrm{M}}$ calculated for the

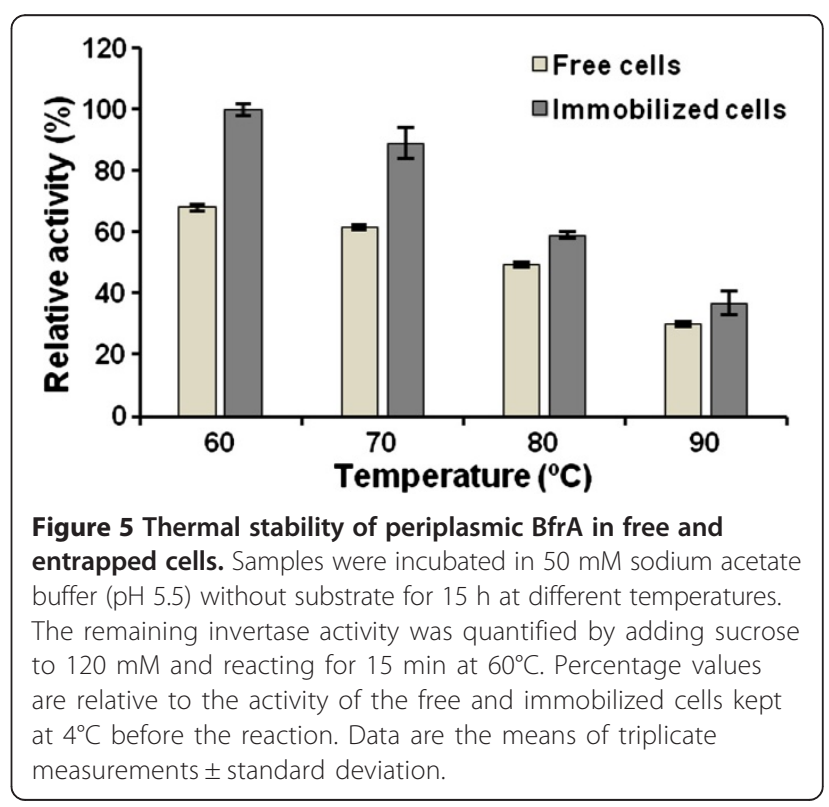


Ca-alginate entrapped cells $(136 \mathrm{mM})$ is almost 1.4-fold higher than that of the free cells $(99 \mathrm{mM})$. Both $K_{\mathrm{M}}$ values exceed the one we reported previously for the free enzyme (51 $\mathrm{mM})$ [20]. These findings indicate that the alginate gel and the cell wall impose a dual diffusional barrier governing the catalytic efficiency of entrapped periplasmic BfrA. Similarly, the entrapment of S. cerevisiae invertase in calcium alginate beads $[7,31]$ or in polyvinyl alcohol hydrogel capsules [34] caused a reduction in the enzyme affinity for sucrose.

Activation energies for the free and entrapped cells were calculated by the Arrhenius plot according to equations $V=6.23-4441.4(1 / \mathrm{T})(\mathrm{r}=0.978)$ and $V=2.62-2293.9$ $(1 / \mathrm{T})(\mathrm{r}=0.964)$, respectively. The activation energy of sucrose hydrolysis by the entrapped cells $(19.15 \mathrm{~kJ} / \mathrm{mol})$ was lower than that displayed by the free cells $(37.09 \mathrm{~kJ} / \mathrm{mol})$. This result strongly supports the assumption that BfrA reaction in the immobilized biocatalyst is limited by internal sucrose diffusion. Similar results have been reported for $S$. cerevisiae invertase immobilized on alginate or other supports $[5,7,37]$.

\section{Complete sucrose hydrolysis by the immobilized biocatalyst in batch and fixed-bed bioreactors}

Batch hydrolysis of cane sugar $(2.04 \mathrm{M})$ by the entrapped cells was conducted in a laboratory-scale stirred reactor operating at 60 and $70^{\circ} \mathrm{C}$. A similar product profile was observed for the time-course experiments at the two temperatures (Figure 6). The complete sucrose inversion took 8 and $10 \mathrm{~h}$ with average productivity of 5.43 and 4.37 gram of substrate hydrolysed per gram of dry beads per hour for the reactions at $70^{\circ} \mathrm{C}$ and $60^{\circ} \mathrm{C}$, respectively. In both cases, the trisaccharide 1-kestose was synthesized reaching to represent above $4 \%(\mathrm{w} / \mathrm{w})$ of the total sugars at time interval $1-3 \mathrm{~h}$, but it was fully hydrolysed at the end of the reaction. $\beta$-fructofuranosidase enzymes commonly possess a side transfructosylating activity when sucrose concentration is above $0.3 \mathrm{M}$ while at lower substrate concentrations only the hydrolytic reaction occurs [38]. The 12-h incubation at $70^{\circ} \mathrm{C}$ caused bead softening and promoted the occurrence of Maillard browning reactions, while the inverted sugar syrup remained colourless in the experiment at $60^{\circ} \mathrm{C}$.

The continuous production of invert sugar was conducted at $60^{\circ} \mathrm{C}$ in a packed-bed reactor with cane sugar concentrations of $0.87,1.46$ and $2.04 \mathrm{M}$ using feed flows of 30, 60 and $120 \mathrm{~mL} / \mathrm{h}$ (Table 1). The highest productivity (3.5 gram of cane sugar hydrolysed per gram of dry beads per hour) was reached when the column was fed with the most concentrated solution $(2.04 \mathrm{M})$ and at the fastest flow $(120 \mathrm{~mL} / \mathrm{h})$. Under this operation condition, $29.7 \%$ of the initial substrate was not converted into products. The increase of the residence time by lowering the flow rate to $30 \mathrm{~mL} / \mathrm{h}$ allowed the complete inversion of cane sugar at all assayed concentrations, but then the biocatalyst productivity dropped to $0.88 \mathrm{~g} / \mathrm{mL} / \mathrm{h}$.

\section{Long-term stability of the immobilised biocatalyst during} batch and continuous production of invert sugar

The operational stability of the entrapped cells was determined during batch and continuous hydrolysis of cane sugar $(2.04 \mathrm{M})$ at $60^{\circ} \mathrm{C}$ (Figure 7 ). The beads retained $98 \%, 70 \%$, and $47 \%$ of its original invertase activity after recycling in a stirred tank reactor for 5,10 , and 15 days, respectively. The biocatalyst behaved even more stable when operated in a packed-bed column. In this case, the beads were still $48 \%$ active after reuse for 21 days with feed flow of $30 \mathrm{~mL} / \mathrm{h}$. The half-life values of BfrA in the entrapped cells during batchwise and continuous operation at $60^{\circ} \mathrm{C}$ were 14 and 20 days, respectively. The lower stability of the beads in the stirred tank reactor may be attributed to the shear stress caused by agitation. The half-life of 20 days is four-fold higher than the value reported for continuous operation at $60^{\circ} \mathrm{C}$ of BfrA covalently immobilized on Glyoxyl-Sepharose CL 4B [24].

Immobilized biocatalysts for the enzymatic production of invert sugar are preferred to stably operate at high
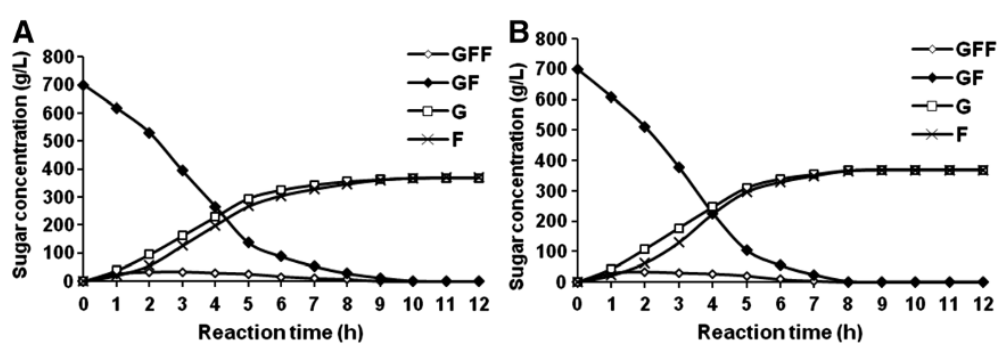

Figure 6 Time course analyses of cane sugar transformation by the calcium-alginate entrapped cells. The experiment was conducted in a laboratory-scale stirred batch reactor operating at $60(\mathbf{A})$ and $70^{\circ} \mathrm{C}(\mathbf{B})$. The beads $(100 \mathrm{~g}$, wet weight) were reacted with $2.04 \mathrm{M}$ cane sugar in $50 \mathrm{mM}$ sodium acetate buffer, pH $5.5(1 \mathrm{~L})$ in a stirred tank reactor. Samples $(0.5 \mathrm{~mL})$ were retrieved every hour and the sugar composition was determined by HPLC. The experiment was replicated three times. Standard deviation of the means was below 10\%. Symbols represent F, fructose; G, glucose; GF, sucrose; GFF, 1-kestose. 
Table 1 Effects of sucrose concentration and feed flow rate on the continuous production of invert sugar

\begin{tabular}{|c|c|c|c|c|c|c|}
\hline \multirow[b]{2}{*}{ Sucrose (M) } & \multirow[b]{2}{*}{$30 \mathrm{~mL} / \mathrm{h}$} & \multicolumn{2}{|c|}{ Hydrolysis (\%) } & \multirow[b]{2}{*}{$30 \mathrm{~mL} / \mathrm{h}$} & \multicolumn{2}{|c|}{ Productivity $(g / g / h)^{*}$} \\
\hline & & $60 \mathrm{~mL} / \mathrm{h}$ & $120 \mathrm{~mL} / \mathrm{h}$ & & $60 \mathrm{~mL} / \mathrm{h}$ & $120 \mathrm{~mL} / \mathrm{h}$ \\
\hline 0.87 & 100 & 100 & 95.7 & 0.38 & 0.75 & 1.50 \\
\hline 1.46 & 100 & 99.1 & 76.2 & 0.63 & 1.25 & 2.50 \\
\hline 2.04 & 99.8 & 93.6 & 70.3 & 0.88 & 1.75 & 3.50 \\
\hline
\end{tabular}

*Productivity is expressed as gram of cane sugar hydrolysed per gram of dry beads per hour.

sucrose concentrations and pasteurization temperatures. Current biocatalysts comprising entrapped $S$. cerevisiae cells or the immobilized invertase exhibit substrate inhibition kinetics and behave rather no stable at temperature exceeding $50^{\circ} \mathrm{C}$ [2]. Immobilized biocatalysts using other microorganisms or enzymes have shown technical limitations such as low thermal stability, decreased catalytic efficiency, substrate inhibition, incomplete sucrose inversion, or by-products formation $[2,13,14,16,30,39-41]$. The immobilized whole-cell biocatalyst developed in this work fully hydrolyzed cane sugar in a highly concentrated solution (2.04 M; 70\%, w/v) during repeated batches or continuous operation at $60^{\circ} \mathrm{C}$ without a remarkable loss of the invertase activity. The resulted colorless syrup is devoid of by-products and does not require subsequent purification or extensive concentration steps prior to commercialization. The fact of using heat-killed cells for immobilization not only avoided the occurrence of sucrose fermentation during the storage and operation periods but also prevented the enzyme from leaking out of the beads, as it did occur when free BfrA was submitted to calcium alginate entrapment. Our current efforts are directed to employ the non-viable entrapped $P$. pastoris cells bearing periplasmic

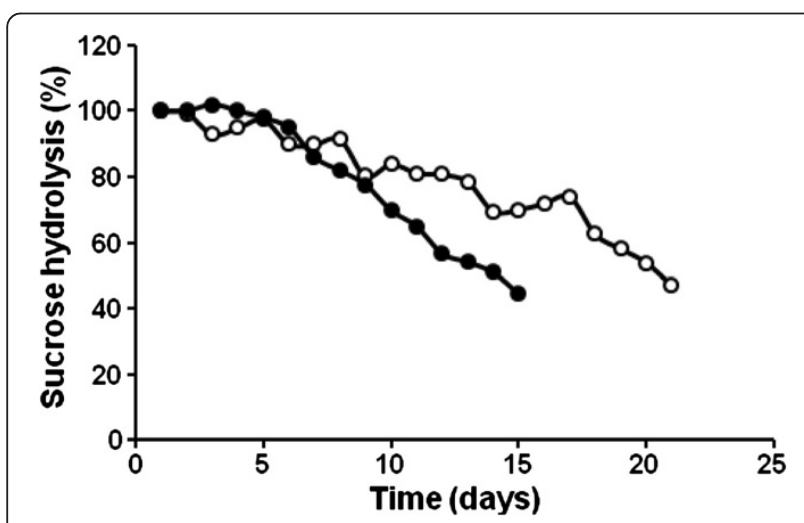

Figure 7 Operational stability of the immobilized cells. Batch and continuous reactions were conducted at laboratory scale in a stirred tank reactor $(\bullet)$ and a packed-bed column (o) using $2.04 \mathrm{M}$ (70\% w/v) cane sugar at $60^{\circ} \mathrm{C}$ and $\mathrm{pH} 5.5$. The stirred tank was operated with $50 \mathrm{~g}$ of wet beads ( $8 \mathrm{~g}$ dry weight) in $1 \mathrm{~L}$ of substrate solution in successive batches repeated every $24 \mathrm{~h}$. The packed-bed column was loaded with $150 \mathrm{~g}$ of wet beads ( $24 \mathrm{~g}$ dry weight) and fed at flow rate of $30 \mathrm{~mL} / \mathrm{h}$.
BfrA as a thermostable biocatalyst for complete sucrose inversion in a packed-bed reactor at industrial scale.

\section{Conclusions}

In this study we have developed a highly thermostable biocatalyst useful for the manufacture of invert syrup. The enzyme of choice was the exo- $\beta$-fructosidase (BfrA) from Thermotoga maritima secreted to the periplasmic space of Pichia pastoris. Heat-killed yeast cells with total retention of the invertase activity were entrapped in calcium alginate beads. The immobilized biocatalyst was successfully used at a laboratory scale for the complete hydrolysis of highly concentrated cane sugar syrup in repeated batches and continuous operation at $60^{\circ} \mathrm{C}$.

\section{Methods}

Microorganism and fed-batch fermentation

Recombinant Pichia pastoris strain PpBfrA(4x) constitutively expressing four codon-optimized copies of the Thermotoga maritima $\beta$-fructosidase gene ( $b f r A)$ fused to the Saccharomyces cerevisiae $\alpha$-factor signal sequence was used throughout this study [20]. Fed-batch fermentation was performed in a $7.5-\mathrm{L}$ fermenter (INFORS) containing $3 \mathrm{~L}$ of growth medium $[1 \%(\mathrm{w} / \mathrm{v})$ cane sugar, $0.5 \%(\mathrm{w} / \mathrm{v})$ yeast extract, $2.2 \%(\mathrm{w} / \mathrm{v})\left(\mathrm{NH}_{4}\right)_{2} \mathrm{SO}_{4}, 1.82 \%$ (w/v) $\mathrm{K}_{2} \mathrm{HPO}_{4}, 0.75 \%$ (w/v) $\mathrm{MgSO}_{4} 7 \mathrm{H}_{2} \mathrm{O}$, and $0.05 \%$ (w/v) $\mathrm{CaCl}_{2} 2 \mathrm{H}_{2} \mathrm{O}$, with vitamins and traces prepared as recommended by Cregg et al. [42] and inoculated with $0.2 \mathrm{~L}$ of a shaking batch culture to an initial cell concentration of $3 \mathrm{~g} / \mathrm{L}$ (wet biomass). The operation conditions during the batch phase were $30^{\circ} \mathrm{C}, \mathrm{pH} 5.5$, agitation at $500 \mathrm{rpm}$, and aeration $1 \mathrm{vvm}$. The fed batch phase started after carbon source depletion, judged by a sharp dissolved oxygen increase. The feeding medium [50\% $(\mathrm{w} / \mathrm{v})$ cane sugar and $0.5 \%(\mathrm{w} / \mathrm{v})$ yeast extract] was added either lineally at a constant flow of $8 \mathrm{~mL} / \mathrm{h} / \mathrm{L}$ of initial volume or exponentially according to the equation $F=\frac{(\mu \mathrm{XoVo})}{Y x / s(S f-S o)} \times e^{\mu t}$ where $\mathrm{F}$ is flow rate, $\mu$ is specific growth rate $\left(0.1 \mathrm{~h}^{-1}\right), X o$ is total amount of cells in the bioreactor (2.4 g dry biomass), $Y x / s$ is yield coefficient ( $0.75 \mathrm{~g}$ dry biomass per gram of sucrose), $V o$ is culture volume (3 L), $S f$ is sucrose concentration of the feeding solution $(500 \mathrm{~g} / \mathrm{L})$ and $S o$ is initial sucrose concentration in the bioreactor $(10 \mathrm{~g} / \mathrm{L})$ and $\mathrm{t}$ is feeding time 
(variable parameter). During the feeding phase agitation and aeration were increased to $900 \mathrm{rpm}$ and $2 \mathrm{vvm}$, respectively. Lineal and exponential fed-batch fermentations were conducted for $54 \mathrm{~h}$. The biomass from the exponential fed-batch fermentation was harvested by centrifugation and used for extraction of periplasmic BfrA and cell immobilization experiments.

\section{Extraction of periplasmic BfrA and endoglycosidase $H_{f}$ treatment}

Yeast biomass (10 g, wet weight) was washed twice with distilled water, resuspended in $40 \mathrm{~mL}$ of $0.1 \mathrm{M} \mathrm{NaHCO}_{3}$ and incubated with shaking $(120 \mathrm{rpm})$ for $1 \mathrm{~h}$ at $37^{\circ} \mathrm{C}$. After centrifugation at $10,000 \times \mathrm{g}$ for $10 \mathrm{~min}$, invertase activity was measured in the cell debris and the soluble extract. BfrA activity was mostly recovered (90\%) in the soluble fraction and the protein purity was determined on SDS-PAGE gels by densitometric analysis. For N-glycosylation analysis, periplasmic BfrA $(10 \mu \mathrm{g})$ was denatured in $100 \mu \mathrm{l}$ of $0.5 \%(\mathrm{w} / \mathrm{v})$ SDS, $1 \%(\mathrm{v} / \mathrm{v})$ $\beta$-mercaptoethanol at $100^{\circ} \mathrm{C}$ for $10 \mathrm{~min}$. After addition of $1 / 10$ volume $1 \mathrm{M}$ sodium citrate buffer $(\mathrm{pH} 5.5)$, the sample was reacted with endoglycosidase $\mathrm{H}_{\mathrm{f}}(\mathrm{New}$ England Biolabs) at $0.25 \mathrm{U} / \mu \mathrm{g}$ of total protein at $37^{\circ} \mathrm{C}$ for $5 \mathrm{~h}$

\section{Cell disruption}

Wet biomass (1 g) was washed in distilled water and resuspended in $0.4 \mathrm{~mL}$ of breaking buffer $[5 \%(\mathrm{v} / \mathrm{v})$ glycerol, $1 \mathrm{mM}$ PMSF, $1 \mathrm{mM}$ EDTA, $50 \mathrm{mM}$ sodium phosphate $\mathrm{pH}$ 6.0]. After addition of equal volume of acid-washed 500- $\mu \mathrm{m}$ glass beads (Sigma), the cells were mechanically lysed by ten cycles of vortex for 30 seconds and ice incubation for 30 seconds. The cell debris and the soluble extract fraction were separated by centrifugation and assayed for invertase activity.

\section{Preparation and storage of calcium alginate beads}

The biomass pellet (150 g, wet weight) was washed, resuspended in deionized water $(300 \mathrm{~mL})$ and incubated at $70^{\circ} \mathrm{C}$ for $30 \mathrm{~min}$ to kill the cells prior to calcium alginate entrapment. The heat-killed cells in amounts of 2.5, 5, 10,15 , and $20 \mathrm{~g}$ (wet weight) were resuspended in distilled water $(50 \mathrm{~mL})$ to achieve final biomass concentrations of 50, 100, 200, 300, and $400 \mathrm{~g} / \mathrm{L}$, respectively. Sodium alginate $(1 \mathrm{~g})$ was added to the cell suspensions at room temperature and mixed thoroughly using a homogenizer. The alginate/cell mixtures were dropped through a fine needle into $37 \mathrm{mM} \mathrm{CaCl} 2$ solution $(500 \mathrm{~mL})$ with constant stirring $(100 \mathrm{rpm})$ using an impeller type marine propeller to avoid droplet aggregation. Gelation time was restricted to one hour after which the $\mathrm{CaCl}_{2}$ solution was discarded. The spherical alginate beads (diameter $2-3 \mathrm{~mm}$ ) were hardened overnight in
$67 \mathrm{mM} \mathrm{CaCl}_{2}$ at $4^{\circ} \mathrm{C}$ and stored in $1.46 \mathrm{M}$ sucrose in $50 \mathrm{mM}$ sodium acetate buffer $(\mathrm{pH} 5.5)$ at $4^{\circ} \mathrm{C}$ before use. Ca-alginate entrapped cells used for biochemical characterization and operation experiments were prepared using wet biomass concentration of $300 \mathrm{~g} / \mathrm{L}$ as described above.

\section{Enzyme assays}

Ca-alginate entrapped cells (25 wet beads) or free cells (25 mg, wet weight) were reacted for $15 \mathrm{~min}$ at $60^{\circ} \mathrm{C}$ in $10 \mathrm{~mL}$ of $120 \mathrm{mM}$ sucrose solution in $50 \mathrm{mM}$ sodium acetate buffer ( $\mathrm{pH} 5.5)$, unless stated otherwise. The reducing sugars released from sucrose hydrolysis were quantified using the dinitrosalicylic acid (DNSA) colorimetric method [43]. An equimolar mixture of glucose and fructose was used for the calibration curve. One unit of invertase activity was defined as the amount of enzyme required for hydrolysis of one $\mu \mathrm{mol}$ of sucrose per minute, under the above-mentioned reaction conditions. The effect of $\mathrm{pH}$ and temperature on the invertase activity of free and immobilized cells was assayed in 15 -min reactions with $120 \mathrm{mM}$ sucrose. The kinetic parameters $K_{\mathrm{M}}$ (apparent Michaelis constant) and $V_{\max }$ (apparent maximum rate) of free and immobilized cells were calculated from Lineweaver-Burk plots by measuring in triplicate the initial reaction rates (Vo) with sucrose ranging $10-200 \mathrm{mM}$ in $50 \mathrm{mM}$ sodium acetate buffer ( $\mathrm{pH} \mathrm{5.5)}$ at $60^{\circ} \mathrm{C}$. The activation energy of free and immobilized cells was calculated using the Arrhenius equation after measuring enzyme activities at 60, 70, 80 and $90^{\circ} \mathrm{C}$ [44]. The storage stability of the biocatalyst at $4^{\circ} \mathrm{C}$ was evaluated every month during one year. Samples of the stored beads were washed tree times in $1.46 \mathrm{M}$ sucrose in $50 \mathrm{mM}$ sodium acetate buffer $(\mathrm{pH}$ 5.5) and assayed for invertase activity in a batch operation mode as described below.

\section{Batch and continuous sucrose hydrolysis}

Batch reactions in time-course experiments were conducted for $12 \mathrm{~h}$ at $60^{\circ} \mathrm{C}$ and $70^{\circ} \mathrm{C}$ using $100 \mathrm{~g}$ of calcium alginate beads (wet weight) incubated with $1 \mathrm{~L}$ of $1.75 \mathrm{M}$ cane sugar solution in $50 \mathrm{mM}$ sodium acetate buffer $(\mathrm{pH} 5.5)$ in a tank reactor with constant stirring $(100 \mathrm{rpm})$. Samples $(0.5 \mathrm{~mL})$ of the reaction mixture were retrieved every $1 \mathrm{~h}$ and the sugar composition was determined by HPLC. The stability of the immobilized biocatalyst operating batchwise was evaluated at $60^{\circ} \mathrm{C}$ for 15 consecutive days. In each cycle, wet beads (50 g) were reacted with $1 \mathrm{~L}$ of the above-mentioned substrate solution for $24 \mathrm{~h}$, recovered by filtration and assayed for residual invertase activity using the DNSA method.

Continuous reactions were performed at $60^{\circ} \mathrm{C}$ in a 250-mL column packed with $150 \mathrm{~g}$ of wet beads using various cane sugar concentrations $(0.87,1.46$ and $2.04 \mathrm{M})$ 
in $50 \mathrm{mM}$ sodium acetate buffer (pH 5.5) at constant flow rates of 30,60 and $120 \mathrm{~mL} / \mathrm{h}$. The stability of the immobilized biocatalyst in continuous operation was evaluated during 21 days of reuse at $60^{\circ} \mathrm{C}$.

\section{Protein and carbohydrate analysis}

Protein concentration was estimated by the Bradford method using bovine serum albumin (BSA) as standard [45]. SDS-PAGE was performed according to [46]. The carbohydrates resulted from the BfrA biocatalyst hydrolase and transferase reactions in a highly concentrated sucrose solution $(2.04 \mathrm{M})$ were quantified by high performance liquid chromatography (HPLC) using an Aminex HPX-42C column $(0.78 \times 30 \mathrm{~cm}$, BIORAD $)$ equipped with a refractive index detector. The column temperature was kept at $85^{\circ} \mathrm{C}$. Water was used as a mobile phase at a flow rate of $0.6 \mathrm{ml} / \mathrm{min}$. Samples were appropriately diluted before injection. Fructose, glucose, sucrose, and 1-kestose $(20 \mathrm{mg} / \mathrm{ml})$ were used as standards.

\section{Competing interest}

The authors declare that they have no competing interest.

\section{Authors' contributions}

DM carried out the Constitutive expression of the synthetic bfrA gene in Pichia pastoris using fermenters. Determined the kinetic parameters of free and immobilized recombinant invertase. Design of biocatalysts of free and immobilized cells. Manuscript draft writing and editorial handling. CM Worked in the cloning and constitutive expression of the synthetic bfrA gene in Pichia pastoris. Determination of copy number integrated into the yeast genome and periplasmic extraction of the recombinant enzyme. FME worked in the establishment of the inactivation and immobilization conditions of the cells. ERP carried out the experiments of the immobilized biocatalyst operation in batch and fixed-bed bioreactors. AS evaluated the Long-term stability of the immobilised biocatalyst during batch and continuous production of invert sugar. LET carried out the screening to get the best invertase producers Pichia pastoris recombinant clones for further fermentation experiments. Carbohydrate analyses by HPLC and sugars quantification. Manuscript writing and editorial handling. RR worked in the analytical support in the determination of kinetic parameters and influence of different parameters in the invertase activity of free and immobilized cells. YQ determined the cell entrapment effect on BfrA thermal stability. Determination of substrate concentration effects on free and immobilized enzyme productivity of intact dead cells. LH was uencharged of the overall scientific management strategies of bfrA cloning and gene expression in P. pastoris. Biochemical characterization of the recombinant enzyme. Manuscript draft writing. All authors read and approved the final version of the manuscript.

\section{Author details}

${ }^{1}$ Fermentation Laboratory, Center for Genetic Engineering and Biotechnology Sancti Spíritus (CIGBSS), Circunvalante Norte S/N, Olivos 3, Apartado Postal 83, Sancti Spíritus 60200, Cuba. ${ }^{2}$ Plant-Microbe Interactions Laboratory, Center for Genetic Engineering and Biotechnology (CIGB), Ave 31 entre 158 y 190, Apartado Postal 6162, Habana 10600, Cuba.

Received: 11 March 2014 Accepted: 21 May 2014

Published: 18 June 2014

\section{References}

1. Andjelković U, Picurić S, Vujčić Z: Purification and characterisation of Saccharomyces cerevisiae external invertase isoforms. Food Chem 2010, 120:799-804.

2. Kotwal SM, Shankar V: Immobilized invertase. Biotechnol Adv 2009, 27:311-322
3. Valerio SG, Alves JS, Klein MP, Rodrigues RC, Hertz PF: High operational stability of invertase from Saccharomyces cerevisiae immobilized on chitosan nanoparticles. Carbohydr Polym 2013, 92:462-468

4. Strand BL, Mørch YA, Skjåk-Bræk G: Alginate as immobilization matrix for cells. Minerva Biotecnol 2000, 12:223-233.

5. Arruda $\mathrm{LMO}$, Vitolo $\mathrm{M}$ : Characterization of invertase entrapped into calcium alginate beads. Appl Biochem Biotechnol 1999, 81:23-33.

6. Rossi-Alva JC, Rocha-Leao MHM: A strategic study using mutant-strain entrapment in calcium alginate for the production of Saccharomyces cerevisiae cells with high invertase activity. Biotechnol Appl Biochem 2003, 38:43-51.

7. Milovanović A, Božić N, Vujčić Z: Cell wall invertase immobilization within calcium alginate beads. Food Chem 2007, 104:81-86.

8. Idris A, Zain NAM, Suhaimi MS: Immobilization of Baker's yeast invertase in PVA-alginate matrix using innovative immobilization technique. Process Biochem 2008, 43:331-338.

9. Safarik I, Sabatkova Z, Safarikova M: Invert sugar formation with Saccharomyces cerevisiae cells encapsulated in magnetically responsive alginate microparticles. J Magn Magn Mater 2009, 321:1478-1481.

10. Najafpour G, Younesi H, Ismail KSK: Ethanol fermentation in an immobilized cell reactor using Saccharomyces cerevisiae. Bioresour Technol 2004, 92:251-260.

11. Gupte A, D'Souza SF: Stabilization of alginate beads using radiation polymerized polyacrylamide. J Biochem Biophys Methods 1999, 40:39-44.

12. Liebl W, Brem D, Gotschlich A: Analysis of the gene for $\beta$-fructosidase (invertase, inulinase) of the hyperthermophilic bacterium Thermotoga maritima, and characterisation of the enzyme expressed in Escherichia coli. Appl Biochem Biotechnol 1998, 50:55-64.

13. Belcarz A, Ginalska G, Lobarzewski J: Immobilized, thermostable S- and F-forms of the extracellular invertase from Candida utilis can hydrolyse sucrose up to $100^{\circ} \mathrm{C}$. Biotechnol Lett 2002, 24:1993-1998.

14. Karandikar S, Prabhune A, Kalele SA, Gosavi SW, Kulkarni SK: Immobilization of thermotolerant Kluyveromyces marxianus on silica aerogel for continuous production of invert syrup. Res J Biotech 2006, 1:16-19.

15. Ferreira MS, De Andrade AV, Kennedy JF: Properties of a thermostable nonspecific fructofuranosidase produced by Cladosporium cladosporioides cells for hydrolysis of Jerusalem artichoke extract. App/ Biochem Biotechnol 1991, 31:1-9.

16. Basha SY, Palanivelu PA: Novel method for immobilization of invertase from the thermophilic fungus Thermomyces lanuginosus. World J Microbiol Biotechnol 2000, 16:151-156.

17. Guimarães LHS, Terenzi HF, Polizeli MLTM, Jorge JA: Production and characterization of a thermostable extracellular $\beta$-d-fructofuranosidase produced by Aspergillus ochraceus with agroindustrial residues as carbon sources. Enzyme Microb Technol 2007, 42:52-57.

18. Giraldo MA, da Silva TM, Salvato F, Terenzi HF, Jorge JA, Guimaraes LHS: Thermostable invertases from Paecylomyces variotii produced under submerged and solid-state fermentation using agroindustrial residues. World J Microbiol Biotechnol 2012, 28:463-472.

19. Muñoz-Gutiérrez I, Rodríguez-Alegría ME, López-Mungía A: Kinetic behavior and specificity of $\beta$-fructosidases in the hydrolysis of plant and microbial fructans. Process Biochem 2009, 44:891-898.

20. Menéndez C, Martínez D, Trujillo LE, Mazola Y, González E, Pérez ER, Hernández L: Constitutive high-level expression of a codon-optimized $\beta$-fructosidase gene from the hyperthermophile Thermotoga maritima in Pichia pastoris. Appl Microbiol Biotechnol 2013, 97:1201-1212.

21. Trujillo LE, Arrieta JG, Dafhnis F, García J, Valdés J, Támbara Y, Pérez M, Hernández L: Fructo-oligosaccharides production by the Gluconacetobacter diazotrophicus levansucrase expressed in the methylotrophic yeast Pichia pastoris. Enzyme Microb Tech 2001, 28:139-144.

22. Menéndez C, Hernández L, Banguela A, País J: Functional production and secretion of the Gluconacetobacter diazotrophicus fructose-releasing exo-levanase (LsdB) in Pichia pastoris. Enzyme Microb Technol 2004 34:446-452.

23. Potvin G, Ahmad A, Zhang Z: Bioprocess engineering aspects of heterologous protein production in Pichia pastoris: A review. Biochem Eng J 2012, 64:91-105.

24. Martínez D, Cutiño-Avila B, Pérez ER, Menéndez C, Hernández L, del MonteMartínez A: A thermostable exo- $\beta$-fructosidase immobilised through rational design. Food Chem 2014, 145:826-831. 
25. Carlson M, Botstein D: Two differentially regulated mRNAs with different $5^{\prime}$ ends encode secreted and intracellular forms of yeast invertase. Cell 1982, 28:1455-154.

26. Tschopp JF, Sverlow G, Kosson R, Craig W, Grinna L: High level secretion of glycosylated invertase in the methylotrophic yeast Pichia pastoris. Bio-Technol 1987, 5:1305-1308.

27. Trujillo LE, Gómez R, Banguela A, Soto M, Arrieta JG, Hernández L: Catalytical properties of N-glycosylated Gluconacetobacter diazotrophicus levansucrase produced in yeast. Electron J Biotechnol 2004, 7:115-123.

28. Ritsema T, Hernández L, Verhaar A, Altenbach D, Boller T, Wiemken A, Smeekens S: Developing fructan-synthesizing capability in a plant invertase via mutations in the sucrose-binding box. Plant J 2006, 48:228-237.

29. Polakovic M, Kudlacova G, Stefuca V, Bales V: Determination of sucrose effective diffusivity and intrinsic rate constant of hydrolysis catalysed by Ca-alginate entrapped cells. Chem Eng Sci 2001, 56:459-466.

30. Ahmed SA: Invertase production by Bacillus macerans immobilized on calcium alginate beads. J App/ Sci Res 2008, 4:1777-1781.

31. Tanriseven A, Doğan S: Immobilization of invertase within calcium alginate gel capsules. Process Biochem 2001, 36:1081-1083.

32. Emregül E, Sungur S, Akbulut U: Polyacrylamide-gelatine carrier system used for invertase immobilisation. Food Chem 2006, 97:591-597.

33. Sanjay G, Sugunan S: Enhanced pH and thermal stabilities of invertase immobilized on montmorillonite K-10. Food Chem 2006, 94:573-579.

34. Rebros M, Rosenberg M, Mlichova Z, Kristofikova L: Hydrolysis of sucrose by invertase entrapped in polyvinyl alcohol hydrogel capsules. Food Chem 2007, 102:784-787.

35. Bergamasco R, Bassetti FJ, de Moraes FF, Zanin GM: Characterization of free and immobilized invertase regarding activity and energy of activation. Braz J Chem Eng 2000, 17:4-7.

36. Bayramoglu G, Karakisla M, Altintas B, Metin AU, Sacak M, Arica MY: Polyaniline grafted polyacylonitrile conductive composite fibers for reversible immobilization of enzymes: Stability and catalytic properties of invertase. Process Biochem 2009, 44:880-885.

37. Vujčić Z, Miloradović Z, Milovanović A, Božić N: Cell wall invertase immobilisation within gelatin gel. Food Chem 2011, 126:236-240.

38. Straathof AJJ, Kieboom APG, Bekkum H: Invertase-catalysed fructosyl transfer in concentrated solutions of sucrose. Carbohydr Res 1986, 146:154-159.

39. Ettalibi M, Baratti JC: Sucrose hydrolysis by thermostable immobilized inulinases from Aspergillus ficuum. Enzyme Microb Technol 2001 28:596-601.

40. Vallejo-Becerra V, Vásquez-Bahena JM, Santiago-Hernández JA, Hidalgo-Lara ME: Immobilization of the recombinant invertase INVB from Zymomonas mobilis on Nylon-6. J Ind Microbiol Biotechnol 2008, 35:1289-1295.

41. Awad GEA, Amer H, El-Gammal EW, Helmy WA, Esawy MA, Elnashar MMM: Production optimization of invertase by Lactobacillus brevis Mm- 6 and its immobilization on alginate beads. Carbohydr Polym 2013, 93:740-746.

42. Cregg JM, Tschopp JF, Stillman C, Siegel R, Akong M, Craig WS, Buckholz RG, Madden KR, Kellaris PA, Davies GR, Smiley BL, Cruze J, Torregrossa R, Velicelebi G, Thill GP: High-level expression and efficient assembly of hepatitis B surface antigen in the methylotrophic yeast Pichia pastoris. Bio-Technol 1987, 5:479-485.

43. Miller GL: Use of dinitrosalicylic acid reagent for determination of reducing sugar. Anal Chem 1959, 31:426-428.

44. Hartmeier W: Immobilized Biocatalysts. Berlin: Springer; 1988.

45. Bradford MM: A rapid sensitive method for the quantification of microgram quantities of protein utilizing the principle of protein-dye binding. Anal Biochem 1976, 72:248-254

46. Laemmli UK: Cleavage of structural proteins during the assembly of the head of bacteriophage T4. Nature 1970, 227:680-685.

doi:10.1186/1475-2859-13-87

Cite this article as: Martínez et al:: Complete sucrose hydrolysis by heat-killed recombinant Pichia pastoris cells entrapped in calcium alginate. Microbial Cell Factories 2014 13:87.

\section{Submit your next manuscript to BioMed Central and take full advantage of:}

- Convenient online submission

- Thorough peer review

- No space constraints or color figure charges

- Immediate publication on acceptance

- Inclusion in PubMed, CAS, Scopus and Google Scholar

- Research which is freely available for redistribution

Submit your manuscript at www.biomedcentral.com/submit
C Biomed Central 